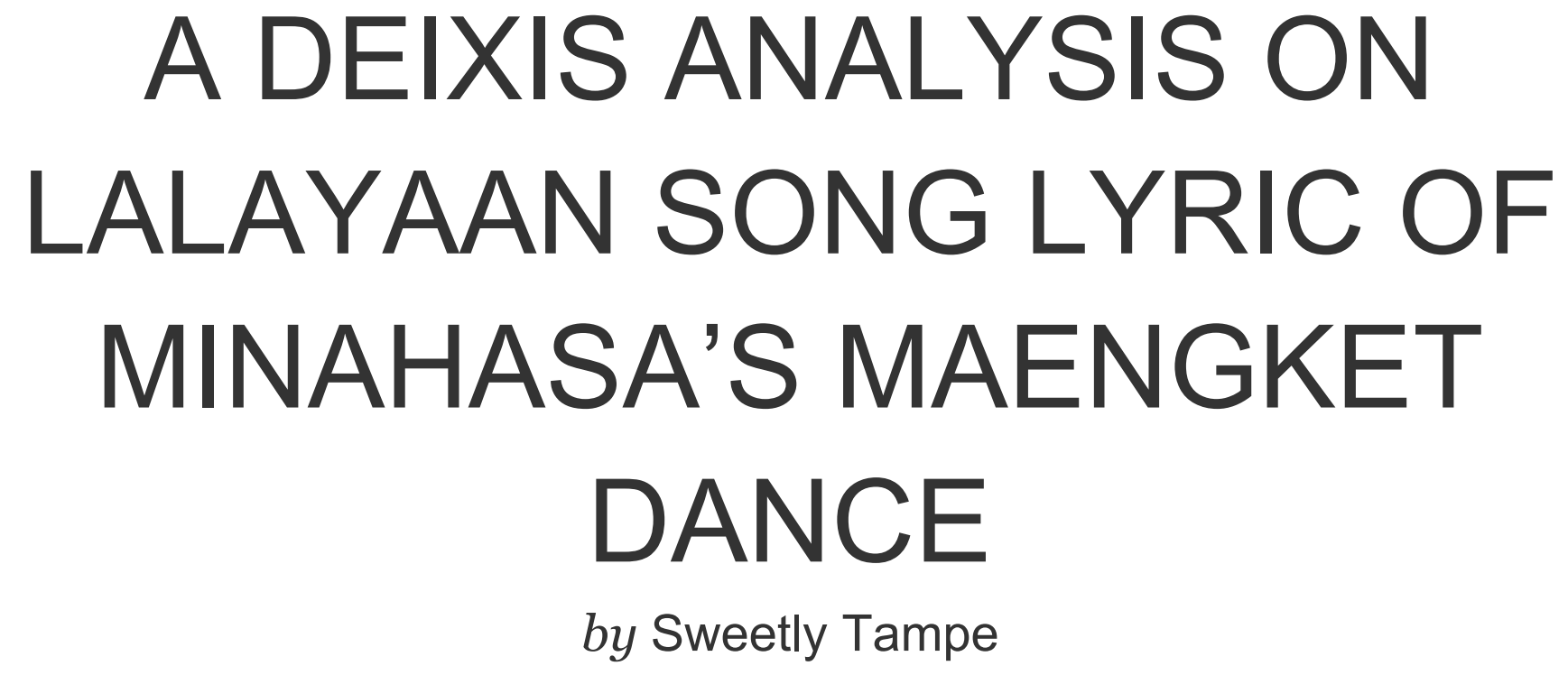

Submission date: 25-Jan-2021 08:35PM (UTC+0700)

Submission ID: 1494013674

File name: article_so_fix_sekali_-_mr_tamps.docx (59.7K)

Word count: 3662

Character count: 18492 


\title{
A DEIXIS ANALYSIS ON LALAYAAN SONG LYRIC OF MINAHASA'S MAENGKET DANCE
}

\author{
Sweetly Tampenawas, Sanerita T. Olii, Jenie Posumah \\ English Language and Literature Study Program, Faculty of Language and Art \\ Universitas Negeri Manado \\ Tondano, Indonesia \\ 18 \\ s14789814@gmail.com
}

\begin{abstract}
This study aims to identify and describe a Deixis on Lalayan song lyric Minahasa's Maengket Dance. It is conducted in order to explain what are the deixis and what were the Deixis meaning used on Lalayaan song lyric Minahasa Maengket Dance. In conducting this study, descriptive method is used. The data are collected through interview and observation, the researchers spent many times to interviewing the informant and note the 12 ata that relation with this study. The data are analyzed by following the steps of data reduction, data display and drawing conclusion. the result shows that there are 3 types of deixis and be find 37 deixis that use on Lalayaan song of Minahasa Maengket Dance. It is suggested that understand deixis analysis on Lalayaan song Minahasa Maengket dance should be consider in order to get the real meaning that the researcher or speaker exactly meaning.
\end{abstract}

Keywords ：Deixis, Maengket, Lalayaan, Song lyric, Pragmatic

\section{INTRODUCTION}

Every human life lives in culture that can express about human life, the ways of human groups prepare knowledge, feature their feelings and ways they act, communication and culture cannot be separated. According to Pangkey, "The culture in North Sulawesi is diverse and worthy of committee and communicated in and abroad' (p.4). Many modern media are used to convey various information. But there are things that can use traditional media as a means to convey information, one of which is the Maengket dance derived from ethnic Minahasa.

Samovar claims that "Maengket dance and culture are two different things, but the existence of culture of its existence is interconnected. A culture can be sustainable and inherited to the next generation through the communication process. Here communications serve as a tool of spreading traditions and cultural values that are imprinted. This makes those communications and culture are two inseparable entities" (p.16). Posumah 
claims that "Maengket dance is basically a culture that emerged by the thoughts that developed in society. This is a manifestation of the general assumption of a culture that when culture emerges there must always be thoughts in society" (p.3).

Maengket dance conveys messages in the form of communication through verbal communication in the form of songs in regional languages and nonverbal communication is in the form of dance. Maengket dance is an ethnic identity and cultural wealth of Minahasa that must be preserved.

Yule claims that "pragmatic is concerned with the study of meaning as communicated by the speaker or the writer and also interpreted by listener or reader" (p.3). It means that sometimes misunderstanding of meaning can occur in language user. The explanation above is closely related to the reference to speech or sentence. So, 17 understanding about reference speech, reader or listener must be able to identify the context of speech.

Saeed argues that "Deixis is a technical term from classical greek deiknymi to 4 how, point out" (p.191). It means that Deixis is a study to interpret the relation of situation with words, phrases, and features are uttered in a sentence. and also Farahmand and hatami claims that "Deixis is traditionally divi 16 l into a number of categories those are person deixis, spatial deixis, temporal deixis, and discourse deixis" (p.222-223). It means deixis are words that pointed at certain things, such as people, objects, place, or time like you, here, now.

Song lyrics have various textual meaning. Generally listeners have different interpretations to understand the meaning of the song. According to Crowther "songs are usually short works music with the words sung" (p.1133). in other ways, it is to convey people's opinions emotions and feelings of other through song lyrics. In real life a song 5 ric provide inspiration for human life. Therefore, sometimes when people listen to the song, they do not just try to understand the meaning of the lyrics, but also the massage from the author to listener through the lyrics.

From that explanation 2nd reason above the researchers decide to create a research entitled "A Deixis Analysis On Lalayaan Song Lyric Of Minah 2 sa's Maengket Dance. The researchers hopes that it can help for the readers easily to understand and to know how deixis used and the meaning in song lyric of Minahasa's Maengket dance expecially Lalayaan song.

\section{RESEARCH METHOD}

This research can be categorized as a qualitative research. It is non 7 I.merical data. According to Cresswell " Qualitative research is descriptive in that the researcher is interested in the process, meaning and understanding gained through words or picture" (p.145). While Mister and Nontje state that "Qualitative method i.8 a method that attempts to examine an object, set conditions, a system of thought $3 \mathrm{r}$ a class of event in the present" ( $p 2)$. In accordance with the approach used in this study, namely qualitative research, the presence of researchers in the field is very important and needed optimally. The researchers are the key instruments that directly observes, interviews and observes the object under study. In this study, the researchers are observer, namely looking for one of the art studios or community groups and observing and interviewing. This research 
uses two data sources. The primary source gives prominent data related to the problem of the research, and the secondary source is an additional source to get the data.The primary source is the original lyric on Lalayaan song Minahasa of Maengket dance. The secondary source is some books such as theories, journals/articles, internet sources, and some materials that support this research. The data is analyzed by using Miles $11 \mathrm{~d}$ Huberman theory the steps are data reduction, data display, and conclusion drawing/verification.

\section{FINDINGS}

\section{Data Reduction}

In the first step of the Miles and Huberman's theory, the researchers collect the data from the song lyric of the Lalayaan Maengket and select several or and categorize according 20 the purpose of this study, namely 3 types of deixis. namely person deixis, time deixis and place deixis.

K1TA

"lumaya tare kita karia"

AKU

"ㅅk ma'wa tumaredem karia"

"Neyaku mande"

\section{$\mathrm{K}_{1} \mathrm{II}$}

"I tow-tow I rake-rake lae $\underline{\mathrm{kai}}$ I nima mule werue"

KARIA

"aku ma'wa tumaredem $\underline{\text { karia }}$ "

TUA

"Sa genenge leos wawaye tua iwawaye tua"

"I wawaye tua lamokan teteane"
WAILAN

"wailan tumow- tow I tow-tow I

rake-rekek la e"

IMBIANGKAN

"Imbiankan paregeregesan karia"

SENDANGAN

"kaweruan wana sendangan"

ANTANA

"mahalik-lik_antana I imenegero genagenangen”

TI LEWETE

"pasasawalen sililisambe ti lewete"

NIROYOR

"ya ungkeke niroyor ungkeke niroyor"

KANTU

"ni, sia, kantu si menge 'keme si menge

"keme eng kendis-kendisan"

SANGALIAN NENDO INANIAN

"sangalian nenndo inania wo tare kita mawerenan"

KENU

"kenu kita nimawereenano"

Data Display

\begin{tabular}{|l|l|l|}
\hline $\begin{array}{l}\text { Type of } \\
\text { Deixis }\end{array}$ & $\begin{array}{l}\text { The } \\
\text { Meaning }\end{array}$ \\
\hline $\begin{array}{l}\text { Person } \\
\text { Deixis "kita" }\end{array}$ & \\
\hline
\end{tabular}




\begin{tabular}{|l|l|}
\hline "lumaya tare & $\begin{array}{l}\text { The sentence } \\
\text { 'lumaya tare } \\
\text { kita karia" } \\
\text { describes the } \\
\text { man who wants } \\
\text { to invite the girl } \\
\text { to dance. Then } \\
\text { the invitation to } \\
\text { dance is used by } \\
\text { the man to } \\
\text { convey the } \\
\text { intentions of the } \\
\text { man. The } \\
\text { pronoun we use } \\
\text { when inviting } \\
\text { the girl is we } \\
\text { are used by the } \\
\text { man to express } \\
\text { togetherness. }\end{array}$ \\
\hline Person \\
"Akum"
\end{tabular}

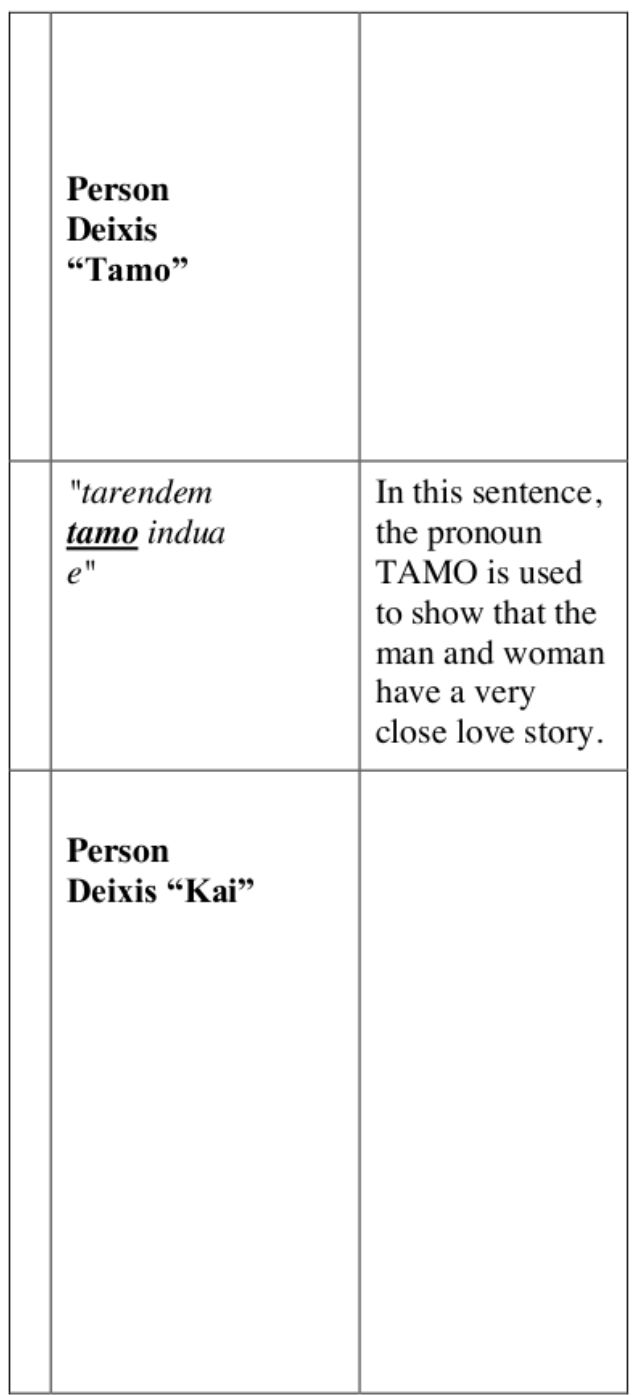




\begin{tabular}{|c|c|}
\hline $\begin{array}{l}\text { "I tow-tow I } \\
\text { rake-rake lae } \\
\text { kai I nima } \\
\text { mule werue" }\end{array}$ & $\begin{array}{l}\text { In this sentence it } \\
\text { shows that they } \\
\text { are very grateful } \\
\text { when God creates } \\
\text { and animates } \\
\text { even for their } \\
\text { success in } \\
\text { building a whole } \\
\text { human being, the } \\
\text { word "KAI" } \\
\text { shows that the } \\
\text { man asks God to } \\
\text { be happy and } \\
\text { glorify them. }\end{array}$ \\
\hline $\begin{array}{l}\text { Person } \\
\text { Deixis } \\
\text { "karia", } \\
\text { " aku ma'wa } \\
\text { tumaredem aia " }\end{array}$ & $\begin{array}{l}\text { In this sentence, } \\
\text { the word karia } \\
\text { shows that the } \\
\text { man wants to } \\
\text { convey his } \\
\text { intentions to the } \\
\text { woman whom he } \\
\text { calls love. }\end{array}$ \\
\hline $\begin{array}{l}\text { Person } \\
\text { Deixis } \\
\text { "Tua" }\end{array}$ & \\
\hline $\begin{array}{l}\text { "Sa genenge } \\
\text { leos wawaye } \\
\text { tua iwawaye } \\
\text { tua" }\end{array}$ & $\begin{array}{l}\text { In this sentence } \\
\text { the parents are } \\
\text { very active } \\
\text { because the } \\
\text { conversation that } \\
\text { the man has with } \\
\text { the woman about } \\
\text { building a } \\
\text { relationship ends }\end{array}$ \\
\hline
\end{tabular}

\begin{tabular}{|c|c|}
\hline & $\begin{array}{l}\text { with the man } \\
\text { asking the } \\
\text { woman to ask } \\
\text { permission to } \\
\text { make a } \\
\text { relationship with } \\
\text { him. }\end{array}$ \\
\hline $\begin{array}{l}\text { "I wawaye } \\
\underline{\text { tua lamokan }} \\
\text { teteane" }\end{array}$ & $\begin{array}{l}\text { In this sentence } \\
\text { after the man } \\
\text { asks the woman } \\
\text { to ask permission } \\
\text { from the parents, } \\
\text { if the woman is } \\
\text { allowed, the man } \\
\text { will build a } \\
\text { relationship with } \\
\text { his family. }\end{array}$ \\
\hline $\begin{array}{l}\text { Person } \\
\text { Deixis } \\
\text { "wailan" }\end{array}$ & \\
\hline $\begin{array}{l}\text { "wailan } \\
\text { tumow-tow I } \\
\text { tow-tow I } \\
\text { rake-rekek la } \\
\text { e" }\end{array}$ & $\begin{array}{l}\text { In this sentence } \\
\text { God is a religious } \\
\text { greeting. The } \\
\text { man and woman } \\
\text { are very grateful } \\
\text { to God who } \\
\text { created them. }\end{array}$ \\
\hline
\end{tabular}

\begin{tabular}{|l|l|l|}
\hline $\begin{array}{l}\text { Type of } \\
\text { Deixis }\end{array}$ & $\begin{array}{l}\text { The } \\
\text { Meaning }\end{array}$ \\
\hline $\begin{array}{l}\text { Place Deixis } \\
\text { "imbiangkan" }\end{array}$ \\
\hline
\end{tabular}




\begin{tabular}{|c|c|}
\hline $\begin{array}{l}\text { "Imbiankn } \\
\text { paregereges } \\
\text { an karia" }\end{array}$ & $\begin{array}{l}\text { In this sentence } \\
\text { explains that the } \\
\text { man wants to } \\
\text { convey his heart in a } \\
\text { comfortable and } \\
\text { comfortable place. } \\
\text { Namely where the } \\
\text { wind blows lightly. }\end{array}$ \\
\hline $\begin{array}{l}\text { Place Deixis } \\
\text { "Sendangan" }\end{array}$ & \\
\hline $\begin{array}{l}\text { "kaweruan } \\
\text { wana } \\
\text { sendangan } \\
\text { " }\end{array}$ & $\begin{array}{l}\text { The use of deixis } \\
\text { which refers to the } \\
\text { sun's place which } \\
\text { means the struggle } \\
\text { needed to get } \\
\text { something. }\end{array}$ \\
\hline $\begin{array}{l}\text { Place } \\
\text { Deixis } \\
\text { "Antana" }\end{array}$ & \\
\hline $\begin{array}{l}\text { "mahalik- } \\
\text { lik antana I } \\
\text { imenegero } \\
\text { gena- } \\
\text { genangen" }\end{array}$ & $\begin{array}{l}\text { The use of deixis } \\
\text { which refers to an } \\
\text { infinite place } \\
\text { means that out side } \\
\text { experiences are } \\
\text { needed in life. }\end{array}$ \\
\hline $\begin{array}{l}\text { Place } \\
\text { Deixis "Ti } \\
\text { lewete" }\end{array}$ & \\
\hline $\begin{array}{l}\text { "pasasawal } \\
\text { en } \\
\text { sililisambe } \\
\text { tilewete" }\end{array}$ & $\begin{array}{l}\text { The use of this } \\
\text { deixis refers to the } \\
\text { association between } \\
\text { young Minahasa } \\
\text { youths who are } \\
\text { looking for a partner } \\
\text { not only in their own } \\
\text { village but also for } \\
\text { friends in }\end{array}$ \\
\hline
\end{tabular}

\begin{tabular}{|c|c|}
\hline & distantareas. \\
\hline $\begin{array}{l}\text { Place } \\
\text { Deixis } \\
\text { "kantu" }\end{array}$ & $\begin{array}{l}\text { This deixis refers to } \\
\text { a place that is far } \\
\text { away, young people } \\
\text { who are looking for } \\
\text { a partner outside } \\
\text { their area, usually } \\
\text { they return to the } \\
\text { country and find a } \\
\text { suitable partner in } \\
\text { their place. }\end{array}$ \\
\hline $\begin{array}{l}\text { “" ni, sia, kantu si } \\
\text { menge keme si } \\
\text { menge keme eng } \\
\text { kendis-kendisan” }\end{array}$ & $\begin{array}{l}\text { The use of deixis } \\
\text { refers to a place that } \\
\text { is far from the } \\
\text { village and far from } \\
\text { the youth in the } \\
\text { content section, } \\
\text { which shows that } \\
\text { the Minahasa youths } \\
\text { have an open } \\
\text { relationship, which } \\
\text { means that their } \\
\text { association is not } \\
\text { only limited to } \\
\text { friends in their } \\
\text { village, but with } \\
\text { friends who come } \\
\text { from far away. } \\
\text { From outside the } \\
\text { area. Even when } \\
\text { looking for a } \\
\text { suitable partner, } \\
\text { Minahasa youths do } \\
\text { not hesitate to travel } \\
\text { long distances. }\end{array}$ \\
\hline $\begin{array}{l}\text { Place } \\
\text { Deixis } \\
\text { "niroyor" }\end{array}$ & \\
\hline
\end{tabular}




\begin{tabular}{|l|l|}
\hline $\begin{array}{l}\text { "ya } \\
\text { ungkeke } \\
\text { niroyor } \\
\text { ungkeke } \\
\text { niroyor" }\end{array}$ & $\begin{array}{l}\text { The use of deixis } \\
\text { refers to a place that } \\
\text { is far from the } \\
\text { village and far from } \\
\text { the youth in the } \\
\text { content section, } \\
\text { which shows that } \\
\text { the Minahasa youths } \\
\text { have an open } \\
\text { relationship, which } \\
\text { means that their } \\
\text { association is not } \\
\text { only limited to } \\
\text { friends in their } \\
\text { village, but with } \\
\text { friends who come } \\
\text { from far away. } \\
\text { From outside the } \\
\text { area. Even when } \\
\text { looking for a } \\
\text { suitable partner, } \\
\text { Minahasa youths do } \\
\text { not hesitate to travel } \\
\text { long distances. }\end{array}$ \\
\end{tabular}

\begin{tabular}{|l|l|}
\hline $\begin{array}{l}\text { Type of } \\
\text { Deixis }\end{array}$ & $\begin{array}{l}\text { The } \\
\text { Meaning }\end{array}$ \\
\hline $\begin{array}{l}\text { Time Deixis "sangalian nendo } \\
\text { inania" }\end{array}$ & $\begin{array}{l}\text { The use of time } \\
\text { deixis refers to a } \\
\text { future time where } \\
\text { when the } \\
\text { association of } \\
\text { sangalian } \\
\text { nenndo inania } \\
\text { wo tare kita } \\
\text { mawerenan" } \\
\text { and Minaha youths } \\
\text { youths have } \\
\text { found a suitable } \\
\text { partner, this } \\
\text { content section } \\
\text { shows that }\end{array}$ \\
\hline
\end{tabular}

\begin{tabular}{|l|l|}
\hline | & $\begin{array}{l}\text { Minahasa youth } \\
\text { have prepared for } \\
\text { their future, are } \\
\text { working hard for } \\
\text { future lives and } \\
\text { the welf are of } \\
\text { their lives. }\end{array}$ \\
\hline $\begin{array}{l}\text { Time Deixis } \\
\text { "kenu" }\end{array}$ & $\begin{array}{l}\text { The use of this } \\
\text { deixis refers to } \\
\text { the present time } \\
\text { where after they } \\
\text { nimawereenan } \\
\text { have matched and } \\
\text { prepared for their } \\
\text { future without } \\
\text { underestimating } \\
\text { the present } \\
\text { because they } \\
\text { already know } \\
\text { each other. }\end{array}$ \\
\hline
\end{tabular}

\section{Person deixis}

\section{KITA (Us and We)}

The pronoun KITA $(U s)$ appears several times in the introduction, content and ending parts of the song lalayaan lyrics. Communication in this text is established between KITA (we) young man and woman. The involvement of the young man and the woman is seen in the introduction which states "lumaya tare kita karia" or "let us dance dear". And also in the contents of the sentence "sangalian nendo anania wo tare kita mawerenan". Or "someday we will meet". And also "kenu kita nimawerenano". Or "now is the time we got to know each other". 
$\operatorname{AKU}(I)$

The pronoun AKU appears in both the introduction and the body. it is used to refer the person speaking. The involvement of the youth appears in the introduction which states "Aku ma'wa tumaredem karia" "I tried to convey the meaning of my heart, dear ", "sa aku wawakan karia" 'Can I have you baby', "Neyaku mande" "I liken", "Mahalik- lik antana aku gena genanen" "I travel the world looking for power' and the content that says "Pinaliliuzku la makasa ko karia" "I have been Trying to forget your imagination darling", "Mangeman uman tare lumakeze genange lumakeze genangku" In fact more memories of me ", "E karia apamo endongku paliuz niko "Taby what should i do to forget you', "Pasasawalen sililisambe ti lewete paharetan genange paharetan umanaku" trying to replace you with another girl who's across there, however just messing up my mind ", "I rara ateku moniko " 1 I will love you sincerely my heart ', "Koku'ni royor - koku'ni royor yang mengoku'ke" ' $\mathrm{He}$ is the voice far awa 1 that? I was amazed to hear that ', and "Nisia Kantu u si mengoku'ke rondoz makalilien genang leose nolatan " " It must be him who voiced that, I was fascinated by me hear it '. the use of the pronoun $\mathrm{AKU}$ in the introduction and content indicates that the young man wants to always reveal his existence to the boy young woman, so the young man told all the efforts he was doing in finding his lover to his pride in his lover.

\section{TAMO (Us)}

The pronoun TAMO (Our) appears at the beginning of the lyrics of the song lalayaan as well as KITA. At the beginning of the song states "tarendem tamo indua $e$ ", which means the love story of the two of us.

\section{KAI (Us)}

The pronoun KAI anpears in the closing section stating "I tow-tow I rake-rake lae kai I nima mule werue" 'Thank you and thank you, be happy, glorify us above business success in building a whole person '. the pronoun KAI refers the same thing with KITA and TAMO that are the both young men and women

\section{KARIA (She)}

The pronoun KARIA appears in the introduction and the body of the subsection first. Actually the pronoun karia can also mean friend, but in the Maengket text This karia means more than friends, namely lovers or Dear. To greet the young woman he loves, the young man use the word replace karia which is a form of greeting that shows romance. in other words, the meaning indicates the relationship between the speaker and the interlocutor very close and romantic. The involvement of the lover (young woman) appears in the section introduction and the content of the first subsection which states "Our tare is quite old karia "'Let's dance baby'," aku ma'wa tumaredem karia " 'I tried convey the meaning of my heart dear ', "Imbiangkan parege-regesan karia" "On the spot the wind blew gently baby ", " sa aku wawakan karia "" Can I have you dear ", and "Lamokan lentue karia " 'I will take the juice dear', and the contents of the first subsection which states "Pinaliliuzku la makasa ko karia" 'Once I tried to forget your shadow dear' and "E karia apamo endongku paliuz niko" 'My dear what must I do to get it forget you '. 


\section{TUA (Parents) They}

The speaker wants to involve the girl's parents in their relationship. Involvement parents is appeared in the introduction which states "Sa genenge leos wawaye tua iwawaye tua" " If you have received permission / directions from your parents, ask! and "I wawaye tua lamokan teteane" "Ask your parents if our hearts are united I will build a rope of friendship '.

\section{WAILAN (God) $\mathrm{He}$}

The pronoun "WAILAN" Or He appears only at the end of song lyric. Then to address god, the pronoun "WAILAN" is used which a form of religious greeting. God's involvement is a peared in the closing section which state "wailan tumow- tow I tow-tow I rakerekek la e" "oh god who create and animates, lift our heart" and finally the use of the pronoun God in the closing section is shown that "the young man and woman" asking god to bless their efforts in fully awakening human beings.

\section{Place deixis}

\section{IMBIANGKAN (Somewhere)}

The first place deixis is in the introduction, namely "IMBIANGKAN" a cool place which is expressed in the utterance : "imbiangkan parege-regesan karia". The use of this deixis refers to a cool place where minahasa youths really like cool place, which means that the balance of nature needs to be maintained continuously.

\section{TI LEWETE (there)}

The next place deixis in the content section, namely "Tilewete" which is expressed in the utterance "pasasawalen sililisambe ti lewete paharetan genange paharetan umanan $k u$ " which means that I once tried to replace you with other girl, money was across there, but it just messed up my mind. The use of this deixis refers to the association between young Minahasa youths who are looking for a partner not only in their own village but also for friends.

\section{KANTU (there)}

The last place deixis in the content section, namely "Kantu" which is expressed in the 1 rics of the song in the content section "ni, sia, Kantu si menge 'keme si menge 'keme eng kendiskendisan" which means that he is laughing there laughing with his dimples. The use of this deixis refers to a place that is far away, young people who are looking for a partner outside their area, usually they return to the country and find a suitable partner in their place. The gentleness of the Minahasan girls, the eloquence of their voices, and the beauty of their dimpled faces are the minahasa women's strengths that ultimately fascinate the Minahasan youth.

\section{Deixis Time}

\section{SANGALIAN DENDO INANIAN (Soon)}

The first time deixis is "Sangalian nendo Inania" which is contained in the content part of the song's lyrics is expressed in the utterance: "sangalian nenndo inania wo tare kita mawerenan". Which means that one day we will meet. 
The use of time deixis refers to a future time where when the association of Minahasa youths. this content section shows that Minahasa youth have prepared for their future are working hard.

\section{KENU (Now)}

The second time deixis is in the content section, namely "Kenu" whose song lyrics are spoken in the utterance of "Kenu kita nimawereenano" which means 'now is the time for us to get to know'. The use of this deixis refers to the present time where after they have matched and prepared for their future without underestimating the present because they already know each other.

\section{Drawing Conclusion}

After finished doing the first step data reduction and the second step data display, the last step to analyze the data in this research is drawing conclusion/verification. In this step or last step, the researcher $\mathrm{h}_{2}$ concluded the deixis such as personal deixis, time deixis and place deixis in the lalayaan song lyric minahasa maengket dance. There are 37 data of deixis: 24 data of personal deixis that refers to person, 11 data of place deixis that refers place and 2 data of time deixis refer to a time.

\section{CONCLUSION}

From the discussion of the study, the researcher has concluded based on analysis in chapter 1 based on the problems listed above. The researchers analyse the deixis in the song lyric according to the title above, namely the song lyric on lalayaan maengket dance. This research also aims to find out and prove that in the third round song lyric, namely I I layaan on Maengket dance there are types of deixis which include : person deixis, time deixis and place deixis can be found in this song lyric. Deixis in the maengket lalayaan song lyric namely person deixis "kita", "tamo,"kai" which means "Us". "karia" which means "dear", and " $A k u$ " which means "I" and "Wailan" which means also "Tua" which means "parents". Place deixis "sendangan" which means "in the east (where the sun rise)", "Atana" which means "world", "Ti lewete" which means "Accros there", deixis Time "Sangalian nendo inania" which means "later one day" and the last "kenu" which means "now is the time".

\section{Suggestion}

After conducting this research, the researchers want to provide input, expecially for young people. Deixis is a very important field to learn, so can be found out the meaning and the function when the deixis referred to expecially person, place and time. This study can help the reader and listener understand what the speaker referred to, by learning the deixis in song lyric. the researcher also wants to give suggestion for every young people to learn about local culture in milenial era as one of important assets to appear the national culture

\section{REFERENCES}

Amirin Tatang, M. Menyusun Rencana Penelitian. Jakarta: Raja Grafindo Persada, 1989. Print

Ary, Donald, Jacobs, Lucy Cheser, Razavieh. Introduction to Research in Education.. New York: Holt, Rinehart, 1995. Print. 
Bogdan, R. C. and Biklen S. K. Qualitative Research for Education: An introduction to theory and methods. Boston : Allyn and Bacon, 1992. Print

Crowther, J. Oxford Advance Leaber's Dictioanary. New York : Oxford University Press. 1995. Print.

Gadzar, J. Pragmatics : implicature, presupposition and logical form. New York : Oxford University.

Goerge, Yule Pragmatics. Oxford University Press. 1996. Print.

John, Cresswell. Research Design : Qualitative and Quantitative Approaches London : Sage Publications 1994. Print.

Levinson, S. C pragmatic. Cambridge University Press. 1983. Print. Miles, M.B. And Huberman, A.M. Qualitative Data Analysis, $2^{\text {nd }}$ ed. USA : sage publication. 1994. Print.

Miles, M.B. And Huberman, A.M. Qualitative Data Analysis, $2^{\text {nd }}$ ed. Usa : Sage publication. 1994.Print

Pangkey, J. A. Perawatan Hiburan dan kesenian Traditional Daerah. Sulawesi utara: 14 epdikbud DirektoratJendral Kebudayaan Direktorat Sejarah dan Nilai Traditional Proyek Inventaris dan Dokumentasi Kebudayaan Daerah. 1986. Print.

Posumah, J. Masa Depan Maengket Dalam Pembinaan dan Pengembangannya. Bahan Diskusi Panel Dies Natalis Universitas Sam Ratulangi. 1985. Print.
Saeed, J. I. Semantics $2^{\text {nd }}$ Edition. United Kingdom: Blackwell publishing.

2003. Print.

Samovar, Larry C. KomunikasiLintas Budaya. Jakarta: Salembe Humantika. 2010. Print.

Sugiyono, 2007. "qualitative quantitative research methods and $R \& D$. Bandung: alfabeta. 2007. Print.

Wijaya, D. and Rohmadi,M Analisis Wacana Pragmatik Kajian Teori dan Analisis. Kadipiro Surakarta : Yuma Pustaka. 2011. Print. 


\section{A DEIXIS ANALYSIS ON LALAYAAN SONG LYRIC OF MINAHASA'S MAENGKET DANCE}

ORIGINALITY REPORT

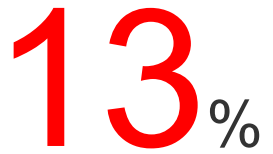

SIMILARITY INDEX
$11 \%$

INTERNET SOURCES
$2 \%$

PUBLICATIONS
$5 \%$

STUDENT PAPERS

\section{PRIMARY SOURCES}

1 icssis.files.wordpress.com

Internet Source

2 www.ejournal.unsa.ac.id Internet Source

3 Submitted to HELP UNIVERSITY

Student Paper

4 repository.usu.ac.id Internet Source

5 Submitted to Inha University

Student Paper

6 Submitted to University of Gloucestershire Student Paper

7 jurnal.unimed.ac.id

Internet Source

8 dinastires.org

Internet Source 
10 Submitted to Universitas Negeri Manado Student Paper

11 www.mdpi.com

Internet Source

12 media.neliti.com

Internet Source

13 issuu.com

Internet Source

14 Bernard Sellato. "Chapter 4 Material Culture Studies and Ethnocultural Identity", Springer Science and Business Media LLC, 2017

Publication

15 digilib.uinsby.ac.id

Internet Source

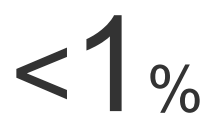

16 repositori.umsu.ac.id Internet Source

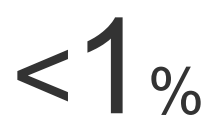

17 digilib.uinsgd.ac.id Internet Source 
On 